\title{
Aquatic and semiaquatic Heteroptera (Insecta) from Pitinga, Amazonas, Brazil
}

Domingos L. V. PEREIRA ${ }^{1}$, Alan Lane de MELO²

\section{ABSTRACT}

A list of aquatic and semiaquatic Heteroptera from a collecting trip to Pitinga, a village in a mining area in the County of Presidente Figueiredo in the Central Amazon is presented. Identified were fifty five species of Heteroptera, distributed in 13 families. Among the insects collected, some are new records for this Amazonian region and in addition 3 apparently undescribed species of Microvelia and one of Paravelia remain for further study.

KEYWORDS: Aquatic Heteroptera, Gerromorpha, Nepomorpha, New state records

\section{Heterópteros (Insecta) aquáticos e semi-aquáticos de Pitinga, Amazonas, Brasil}

\section{RESUMO}

Uma lista de heterópteros aquáticos e semi-aquáticos coletados durante uma viagem a Pitinga, uma área de mineração no município de Presidente Figueiredo, na Amazônia Central, é apresentada. Foram coletadas 55 espécies de Heteroptera, distribuídas em 13 famílias. Entre os insetos coletados, alguns são registros novos para essa região amazônica.

PALAVRAS-CHAVE: Heterópteros aquáticos, Gerromorpha, Nepomorpha, Distribuição, Amazônia.

${ }^{1}$ Coordenação de Pesquisas em Entomologia, Instituto Nacional de Pesquisas da Amazônia - INPA, Avenida André Araújo, 2936, Manaus, AM. CEP 69083-000. e-mail: dleo@inpa. gov.br

${ }^{2}$ Laboratório de Taxonomia e Biologia de Invertebrados / Departamento de Parasitologia / Instituto de Ciências Biológicas da UFMG, CP 486. CEP 30123-970, Belo Horizonte, MG e-mail: aldemelo@icb.ufmg.br 


\section{INTRODUCTION}

The Heteroptera comprise a widely distributed group of insects of vast economic and medical interest. A large majority of its species is terrestrial but some of them are well adapted to aquatic or semiaquatic life and are efficient predators. These forms are found in a great variety of aquatic environments from stagnant pools to running water and from leaf axils of bromeliads to open ocean.

Data on distributional patterns and habitat preferences of aquatic and semiaquatic Heteroptera in Brazil, within and among several habitats, as well as other basic biological and ecological information, are found dispersed in the literature. However, they are mainly for regional faunas of southern Brazil (Nieser, 1994; Nieser \& Pelli, 1994; Nieser \& Melo, 1997, 1999a, b; Nieser et al., 1997, 1999; Nieser \& Polhemus, 1999; Nieser \& Chen, 2002; Nieser \& Lopez-Ruf, 2001; Vianna \& Melo, 2002, 2003; Goulart et al., 2002; Melo \& Nieser, 2004).

Problems with water quality and degradation of aquatic habitats are associated with human population expansion and to the type of land use which contribute to disrupt the ecological equilibrium of a region. Notwithstanding, the basic literature on invertebrate-aquatic communities focuses mainly on pathogens and some invertebrate vectors of parasitic diseases, and attempts to establish and select conservation priorities for riverine habitats within these areas are few.

In 2000, one of the authors (DLVP), aiming to obtain information regarding aquatic and semiaquatic Heteroptera in a mining area in central Amazonia, made some collecting trips to Pitinga, a village in the municipality of Presidente Figueiredo. Since no previous record of water bugs from this area is known to us, the results of that collecting trip are presented here.

\section{MATERIAL AND METHODS}

\section{STUDY AREA}

The Presidente Figueiredo municipality, founded in 1981, is located ca $107 \mathrm{~km}$ north of Manaus, covering an area of about $24,781 \mathrm{~km}^{2}$, and is made up of several biological reserve and protected indigenous areas such as the Waimiri-Atroari.

Pitinga is a small mining town situated in the WaimiriAtroari reserve, about $310 \mathrm{~km}$ from Manaus and $70 \mathrm{Km}$ south of the Equator ( $00^{\circ} 47^{\prime} 28.7^{\prime \prime}$; $\left.60^{\circ} 04^{\prime} 12.2^{\prime \prime} \mathrm{W}\right)$. This region is covered by tropical rain forest with an annual rainfall of more than $2000 \mathrm{~mm}$. The typical geomorphologycal sets are composed of Palaeozoic sedimentary soils from pre-Cambrian age related to the Prosperança formation of siliciclastic rocks with dense drainage and shows subvulcanic intrusive and effusive granitic rocks (Radam, 1978; Nogueira \& Sarges, 2001; Muller \& Carvalho, 2005).

Samples were taken from several places in the village, which were considered to represent possible habitats for Heteroptera and to account for the ecological diversity of the aquatic environments. The sites included some ponds, puddles with rock and strips of vegetation on sand, bottom with small boulders, sand and or gravel, and the Pitinguinha and Perdigoto, rivers which are slow to moderately fast flowing, over $1 \mathrm{~m}$ deep in some places, with rapids and riffles at quiet parts.

Macroinvertebrate samples were taken by sweeping the water column, edges and bottom of water bodies with entomological hand nets. The collected material was placed in plastic trays and the insects were sorted from detritus and transferred to vials containing $80 \%$ ethanol. In the laboratory, each sample was examined under a dissecting microscope and species identification was performed basically according to Nieser \& Melo (1997). The sampled material was deposited in the entomological collection in the Department of Parasitology of the Federal University of Minas Gerais (DPIC).

\section{RESULTS}

Fifty five species of Heteroptera, distributed in 13 families, were collected. The dominance of Gerromorpha species (31) was found in all sites. Veliidae and Gerridae were the commonest families of Gerromorpha, making up 49.1\% (27 species) and Microvelia spp. more than 10\% (seven) of all recorded species from the Pitinga vicinities. Twenty nine species were found in Pitinguinha, 26 in Perdigoto creeks, some of which were common to both. In the other sites sampled, which represent more lentic habitats than the above mentioned creeks, the 32 species of Heteroptera found were grouped as other sites.

Some species of these families were described only from the Amazonian region and others are widespread and commonly found among marginal vegetation in standing waters of ponds or small puddles and in slow to moderately fast flowing streams from other regions of southern Brazil. Naucoridae was the major family of Nepomorpha (24) collected with 7 species $(29.1 \%)$ recorded in the study area.

The great number of species found in a few types of ambient showed low frequency, but Paravelia sp. and Rhagovelia spp. were abundant. The checklist of species in the habitats sampled is shown in Table 1. 
Table 1 - Species of aquatic Heteroptera collected in several sites in Pitinga, municipality of Presidente Figueiredo (Amazonas, Brazil), where $(-)=$ absence and $(+)=$ presence.

\begin{tabular}{|c|c|c|c|}
\hline & 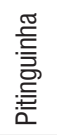 & $\begin{array}{l}\text { 윰 } \\
\text { 음 } \\
\text { 임 }\end{array}$ & 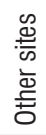 \\
\hline \multicolumn{4}{|l|}{ Belostomatidae } \\
\hline Belostoma discretum Montandon, 1903 & - & - & + \\
\hline Belostoma plebejum (Stål, 1858) & + & + & + \\
\hline Belostoma micantulum (Stål, 1858) & - & + & - \\
\hline Lethocerus sp.(larva) & - & - & + \\
\hline \multicolumn{4}{|l|}{ Corixidae } \\
\hline Heterocorixa similis Nieser, 1970 & - & + & - \\
\hline Tenagobia incerta Lundblad, 1928 & + & + & - \\
\hline \multicolumn{4}{|l|}{ Gelastocoridae } \\
\hline Gelastocoris flavus (Guérin-Méneville, 1835) & - & - & + \\
\hline \multicolumn{4}{|l|}{ Naucoridae } \\
\hline Ambrysus bifidus La Rivers \& Nieser, 1972 & + & + & - \\
\hline Ambrysus partridgei De Carlo, 1968 & + & - & - \\
\hline Ambrysus usingeri La Rivers, 1952 & + & + & - \\
\hline Ctenipocoris spinipes (Montandon, 1897) & - & - & + \\
\hline Limnocoris birabeni De Carlo, 1967 & - & - & + \\
\hline Limnocoris burmeisteri De Carlo, 1967 & + & + & - \\
\hline Limnocoris illiesi De Carlo, 1967 & + & - & + \\
\hline \multicolumn{4}{|l|}{ Nepidae } \\
\hline Ranatra macrophthalma Herrich-Schäffer, 1853 & + & + & - \\
\hline Ranatra subinermis Montandon, 1907 & - & - & + \\
\hline Ranatra tuberculifrons Montandon, 1907 & + & - & - \\
\hline \multicolumn{4}{|l|}{ Notonectidae } \\
\hline Buenoa truxali Nieser, 1968 & - & - & + \\
\hline Martarega membranacea White, 1879 & + & + & + \\
\hline Notonecta pulchra Hungerford, 1926 & - & - & + \\
\hline \multicolumn{4}{|l|}{ Ochteridae } \\
\hline Ochterus aeneifrons surinamensis Nieser, 1975 & - & - & + \\
\hline Ochterus perbosci (Guérin-Méneville, 1843) & - & - & + \\
\hline Ochterus tenebrosus Nieser, 1975 & - & - & + \\
\hline \multicolumn{4}{|l|}{ Pleidae } \\
\hline Neoplea absona Drake \& Chapman, 1953 & + & - & + \\
\hline \multicolumn{4}{|l|}{ Gerridae } \\
\hline Brachymetra lata Shaw, 1933 & + & + & - \\
\hline Cryptobatoides bruneus Polhemus, 1991 & + & - & - \\
\hline Cylindrosthetus palmaris Drake \& Harris, 1934 & - & + & - \\
\hline Limnogonus aduncus Drake \& Harris, 1933 & + & + & + \\
\hline Limnogonus hialinus (Fabricius, 1803) & - & - & + \\
\hline Neogerris lotus (White, 1879) & - & - & + \\
\hline Neogerris visendus (Drake \& Harris, 1934) & - & - & + \\
\hline Ovatametra obesa Kenaga, 1942 & + & - & + \\
\hline Rheumatobates crassifemur esakii Schroeder, 1931 & - & - & + \\
\hline Telmatometra fusca Kenaga, 1941 & - & - & + \\
\hline \multicolumn{4}{|l|}{ Hebridae } \\
\hline Hebrus sp. (larva) & - & - & + \\
\hline Merragata hebroides White, 1877 & - & - & + \\
\hline
\end{tabular}

\begin{tabular}{|c|c|c|c|}
\hline \multicolumn{4}{|l|}{ Hydrometridae } \\
\hline Hydrometra argentina Berg, 1879 & - & + & + \\
\hline \multicolumn{4}{|l|}{ Mesoveliidae } \\
\hline Mesovelia amoena Uhler, 1894 & + & + & + \\
\hline \multicolumn{4}{|l|}{ Veliidae } \\
\hline Microvelia hinei Drake, 1920 & + & + & - \\
\hline Microvelia mimula White, 1879 & + & + & - \\
\hline Microvelia pulchella Westwood, 1834 & + & + & - \\
\hline Microvelia venustatis Drake \& Harris, 1933 & - & - & + \\
\hline Microvelia sp.1 & + & - & + \\
\hline Microvelia sp.2 & - & - & + \\
\hline Microvelia sp.3 & - & - & + \\
\hline Rhagovelia amazonensis Gould, 1931 & + & + & - \\
\hline Rhagovelia evides Bacon, 1948 & + & + & - \\
\hline Rhagovelia tenuipes Champion, 1898 & + & + & - \\
\hline Rhagovelia traili (Buchanan-White, 1879) & - & - & + \\
\hline Paravelia bulliallata Polhemus \& Polhemus, 1984 & + & + & - \\
\hline Paravelia dilatata Polhemus \& Polhemus, 1984 & + & + & - \\
\hline Paravelia sp. & + & + & + \\
\hline Stridulivelia stridulata (Hungerford, 1929) & + & + & - \\
\hline Stridulivelia tersa (Drake \& Harris, 1941) & + & + & - \\
\hline Stridulivelia transversa (Hungerford, 1929) & + & + & - \\
\hline
\end{tabular}

\section{DISCUSSION}

Among the insects collected, some are new records for the Amazonian region, including Belostoma plebejum, Rhagovelia tenuipes (known from the states of Pará and Minas Gerais), Ochterus aeneifrons surinamensis, a subspecies described from Suriname by Nieser (1975), and undescribed species of Microvelia. Apparently, this area is rich in Microvelia. One of the species of this genus may have been previously described, but not the others, such as the Paravelia.

The sampling sites, comprising permanent and semipermanent lotic and lentic habitats in the current study, did not present distinct family compositions. However, the relative homogeneity of species distribution among Nepomorpha and Gerromorpha, suggesting a lower variability on the species composition, should be viewed carefully, because some of them probably could be displaced by others, ecologically more tolerant, from the same genera as consequence of changes in general habitat traits from human impact. As far as we know, no previous study from unmodified aquatic bodies or species list was given, yet we are unable to affirm whether or not the present records represent a poor diversity of heteropteran for this region. In fact standing water, leaf litter and emergent macrophytes that are rare in some sites sampled could influence the distribution of these insects.

A few studies of aquatic insects associated with mining activities deal with high acidified water bodies (Jarvis \& Younger, 1997; Winterbourn et al., 2000), or they exclude the Gerromorpha from data analysis (Proctor \& Grigg, 
2006) and in a stricto sensu are not applicable in the present report. The results obtained suggest that the mining activities did not exclude the heteropteran community from this area, despite evidence that biotic and abiotic factors can influence population distribution and community assembly in different ways. Among them, the water physicochemical properties, structural patterns of the water sources and water permanence, presence of macrophytes in shaping aquatic habitats, physiological tolerance, colonization abilities and food availability. On the other hand, some studies on species composition, correlation between age and size of aquatic habitats in a mining area were verified (Palmer, 1981; Adams \& Robbins, 1982, 1990) but, studies on heteropteran community structure in a wide range of habitats could not be directly compared. However, they support some of the patterns suggested by the present study (Nieser, 1975; García-Avilés et al., 1996; González-Martínez \& Valladares-Díez, 1996; Larsen \& Olson, 1997; Goulart et al., 2002; Vianna \& Melo, 2003). Studies on heteropteran fauna from several natural water bodies far from mining sites in southern Brazil have shown a similar distributional pattern in family composition, and the number of species sampled was also similar (Vianna \& Melo, 2003; Melo \& Nieser, 2004; Pelli et al., 2006; Sousa et al., 2006).

Although many of the species recorded are ecologically important, additional information on distributional patterns and faunistic aspects of the aquatic and semiaquatic Heteroptera in Pitinga is needed for a definitive biogeographycal analysis, as this list is probably not complete.

\section{ACKNOWLEDGEMENTS}

We thank Dr. Fernando A. Silveira for his helpful comments on the manuscript.

\section{LITERATURE CITED}

Adams, J.; Robbins, H. J. 1982. The invertebrate fauna of Northumberland mining subsidence pools. Bulletin of the British Ecologycal Society, 13: 139-140.

Adams, J. ; Robbins, H. J. 1990. The fauna of mining subsidence pools in Northumberland. 1990. Transactions of the Natural History Society of Northumberland, 55: 28-38.

García-Avilés, J.; Puig, M. A.; Soler, A. G. 1996. Distribution and associations of the aquatic Heteroptera of the Balearic Islands (Spain). Hydrobiologia, 324: 209-217.

González-Martínez, S. C.; Valladares-Díez, L. F. 1996. The community of Odonata and aquatic Heteroptera (Gerromorpha and Nepomorpha) in a rehabilitated wetland: the Laguna de la Nava (Valencia, Spain). Archiv fuer Hydrobiologie, 136: 89104.

Goulart, M.; Melo, A. L.; Callisto, M. 2002. Qual a relação entre parâmetros ambientais e a diversidade de heterópteros aquáticos em nascentes de altitude? Bios, 10: 63-76.
Jarvis, A. P. ; Younger, P. L. 1997. Dominating chemical factors in mine water induced improverishment of the invertebrate fauna of two streams in the Durham coalfield, UK. Chemical Ecology, 13:249-270.

Larsen, E.; Olson, C. 1997. Aquatic Coleoptera and Hemiptera of Organ Pipe Cactus National Monument, Arizona. Entomological News, 108: 34-42.

Melo, A. L.; Nieser, N. 2004. Faunistical notes on aquatic Heteroptera of Minas Gerais (Brazil). An annotated list of Gerromorpha and Nepomorpha collected near Januária, MG. Lundiana, 5: 43-49.

Muller, A. J.; Carvalho, A. S. 2005. Uso de Produtos CERBS para o Zoneamento Geoambiental de Presidente Figueiredo, no Amazonas. In: Simpósio Brasileiro de Sensoriamento Remoto (SBSR), XII: 1035-1044. Goiânia. INPE. Available at http:// marte.dpi.inpe.br/col/ltid.inpe.br/sbsr/2004/11.20.20.13/ doc/1035.pdf. Accessed in 12/07/2005.

Nieser, N. 1975. The Water Bugs (Heteroptera: Nepomorpha) of the Guyana region. Studies of the Fauna of Suriname and the other Guyanas, 16: 1-308, 24 pls.

Nieser, N. 1994. A new species and a new status in Neogerris Matsumura (Heteroptera: Gerridae) with a key to American species. Storkia, 3: 27-37.

Nieser, N.; Pelli, A. 1994. Two new Buenoa (Heteroptera: Notonectidae) from Minas Gerais (Brazil). Storkia, 3: 1-4.

Nieser, N.; Melo, A. L. 1997. Os Heterópteros Aquáticos de Minas Gerais. Belo Horizonte, UFMG. 180pp.

Nieser, N.; Melo, A. L., Pelli, A.; Barbosa, N. D. C. 1997. A new species of Buenoa (Heteroptera: Notonectidae) from Minas Gerais (Brazil). Entomologische Berichten, Amsterdam, 57: 129135.

Nieser, N.; Melo, A. L. 1999a. A new species of Halobatopsis (Heteroptera: Gerridae) from Minas Gerais (Brazil), with a key to species. Entomologische Berichten, Amsterdam, 59: 97-102.

Nieser, N.; Melo, A. L. 1999b. Limnocoris bergi De Carlo, a new synonym of L. brasiliensis De Carlo (Heteroptera, Naucoridae). Revista Brasileira de Zoologia, 16: 1235-1236.

Nieser, N.; Polhemus, D. A. 1999. Four new species of Rhagovelia (Heteroptera: Veliidae) from Minas Gerais (Brazil), with a key to the regional species of the angustipes complex. Aquatic Insects, 21: 53-76.

Nieser, N., Pelli, A.; Melo, A. L. 1999. Two new Ambrysinae (Heteroptera: Naucoridae) from Minas Gerais, Brazil. Acta Societatis Zoologicae Bohemicae, 63: 157-163.

Nieser, N.; Lopez-Ruf, M. 2001. A review of Limnocoris Stål (Heteroptera: Naucoridae) in Southern South America east of the Andes. Tijdschrift voor Entomologie, 144: 261-328.

Nieser, N.; Chen, P. P. 2002. Six new species of Neotrephes China (Heteroptera: Helotrephidae) from Brazil, with a key to Neotropical Helotrephidae. Lundiana, 3: 21-40.

Nogueira, A. C. R.; Sarges, R. R. 2001. Characterization and genesis of waterfalls of the Presidente Figueiredo region, northeast State of Amazonas, Brazil. Anais da Academia Brasileira de Ciências, 73: 287-301. 


\section{ACTA}

Palmer, M. 1981. Relationship between species richness of macrophytes and insects in some water bodies in the Norfolk breckland. Entomologist's monthly Magazine, 117: 35-46.

Pelli, A.; Nieser, N.; Melo, A. L. 2006. Nepomorpha and Gerromorpha (Insecta: Heteroptera) from Serra da Canastra, southwestern Minas Gerais, Brazil. Lundiana, 7: 67-72.

Procter, H.; Grigg, A. 2006. Aquatic invertebrates in a final void water bodies at na open-cut coal mine in central Queensland. Australian Journal of Entomology, 45: 107-121.

RADAM, 1978. Programa de Integração Nacional. Levantamentos de Recursos Hidricos. v. 10 folha SA 21 Radam (projeto) DNPM, Ministério das Minas e Energia. Brasil. p. 86.

Souza, M. A. A.; Melo, A. L. 2006; Vianna, G. J. C. Heterópteros aquáticos oriundos do Município de Mariana, MG. Neotropical Entomology, 36: 803-810.
Vianna, G. J. C.; Melo, A. L. 2002. Aquatic Heteroptera as host of Temnocephala Blanchard (Platyhelminthes: Temnocephalidae) in Minas Gerais, Brazil. Lundiana, 3: 151-153.

Vianna, G. J. C.; Melo, A. L. 2003. Distribution patterns of aquatic and semi aquatic Heteroptera in Retiro das Pedras, Brumadinho, Minas Gerais, Brazil. Lundiana, 4: 125-128.

Winterbourn, M. J.; McDiffett, M. J.; Eppley, S. J. 2000. Aluminium and iron burdens of aquatica biota in New Zealand streams contaminated by acid mine drainage: effects of trophic level. Science of the total Environment, 254: 45-54.

Recebido em 06/10/2005

Aceito em 10/06/2007 
